\title{
IMPLICATIONS OF APHID FLIGHT PATTERNS FOR PEST MANAGEMENT OF POTATOES
}

\author{
M.A.W. STUFKENS, D.A.J. TEULON, D. NICOL \\ and J.D. FLETCHER
}

\begin{abstract}
New Zealand Institute for Crop \& Food Research Limited, Private Bag 4704, Christchurch
\end{abstract}

\begin{abstract}
The flight patterns of aphid vectors of the potato leaf roll virus were monitored for 18 years with a $7.5 \mathrm{~m}$ high suction trap at Lincoln, Canterbury. Analysis of the collected samples indicates that late-spring and autumn aphid flight peaks vary considerably between seasons and years in their timing, magnitude and duration, which may have important implications for aphid and virus control in potato crops. The potential of a virus forecasting system based on aphid flight monitoring to support potato growers' pest management decisions is discussed.

Keywords: potato, aphid flight, potato leaf roll virus, decision support system.
\end{abstract}

\section{INTRODUCTION}

Virus management in the potato industry is based on the planting of virus-tested seed potato tubers. Approximately $95 \%$ of seed now in use in New Zealand is certified from a pathogen-tested programme (R. Genet, pers. comm.) with about $95 \%$ of seed potatoes grown in Canterbury. Use of pathogen-tested potatoes has led to yield increases of between 0-60\% (mostly between 10-30\%) (Ovenden et al. 1985). However, in recent years there has been a noticeable increase in virus disease, especially the aphid-transmitted potato leaf roll virus (PLRV) (Fletcher 1997), which has led to difficulty in maintaining high quality potato seed production. Increased virus incidence has focused attention on the need to develop better methods for aphid and virus management.

At least 28 aphid species in New Zealand have been identified as actual or potential potato virus vectors (D.A.J. Teulon, unpubl. data). Nine of these species can transmit PLRV to potatoes. However only three species, the green peach aphid, Myzus persicae, the foxglove aphid, Aulacorthum solani and the potato aphid, Macrosiphum euphorbiae, have been reported to be common on potatoes in New Zealand, with the green peach aphid the most common (Cottier 1931; Close 1965; Claridge 1972; Lowe 1973; Miln 1978; Webby 1988). This has been confirmed by recent surveys of crops in Canterbury (M.A.W. Stufkens, unpubl. data). All three aphid species also form colonies in potato crops and cause direct feeding damage. The green peach aphid is the most efficient vector of PLRV (Radcliffe et al. 1993; Salazar 1996). Another species, the melon or cotton aphid, Aphis gossypii, has recently become an important virus vector in potatoes in Europe, partly due to its resistance to various pesticides (Rongai et al. 1998). This aphid is a vector of several potato viruses but is not known to transmit PLRV. The melon aphid has been reported on potatoes in New Zealand in small numbers (Webby 1988, M.A.W. Stufkens, unpubl. data) and some insecticide resistant populations have been found on chrysanthemums (Martin and Workman 1997). However, the pest status of this aphid on potatoes in New Zealand is not clear and it was not included in this study.

In recent years a successful virus forecasting system, based on aphid monitoring in suction traps, has been developed for cereal crops in Canterbury (Teulon and Stufkens 1998; Teulon et al. 1999). As a first step in the possible development of an aphid monitoring - virus forecasting system to support potato (especially seed potato)

New Zealand Plant Protection 53:78-82 (2000) 
growers' pest management decisions, we examined flight patterns of potato virus vectors caught in a $7.5 \mathrm{~m}$ suction trap at Lincoln, Canterbury. The trap, which was emptied weekly, has been in place from 1981 to 1999.

\section{METHODS}

Aphid flight activity was monitored at a height of $7.5 \mathrm{~m}$ with a suction trap at Lincoln, Canterbury from January 1981 to December 1999. The enclosed-cone suction trap had a $305 \mathrm{~mm}$ diameter aerofoil fan drawing about $60 \mathrm{~m}^{3}$ of air per minute (Johnson and Taylor 1955). From 1981 to 1998 the suction trap was placed at the top of a telegraph pole which had to be climbed to empty the collecting jar (Farrell and Stufkens 1992). In 1998, the trap was modified to allow it to be serviced from ground level. A long metal cylinder $300 \mathrm{~mm}$ in diameter by $6.5 \mathrm{~m}$ was attached to the top of the suction trap and both were supported on a telegraph pole. The fan of the suction trap was at a height of $1 \mathrm{~m}$. Flying aphids (and other insects and various debris) were continuously sucked through the open end of the cylinder $7.5 \mathrm{~m}$ above ground and then into a collecting jar. The collecting jar was cleared weekly and the aphids sorted, identified and counted in the laboratory.

Aphid flight activity for the three main PLRV virus vectors, the green peach aphid, the foxglove aphid and the potato aphid, were analysed by graphing aphid numbers caught in the suction trap per week against time for each growing season (July to June). Trends in flight patterns, seasonal variations and duration of peaks were identified.

\section{RESULTS AND DISCUSSION}

The flight patterns of the three main potato virus vectors reflected the bimodal pattern typical of aphids in Canterbury (Lowe 1966, 1968) with relatively large numbers of aphids caught in late spring/early summer (October to December) and autumn (March to June), and relatively low numbers caught in mid-summer and winter. Of the three species, the green peach aphid was caught in much greater

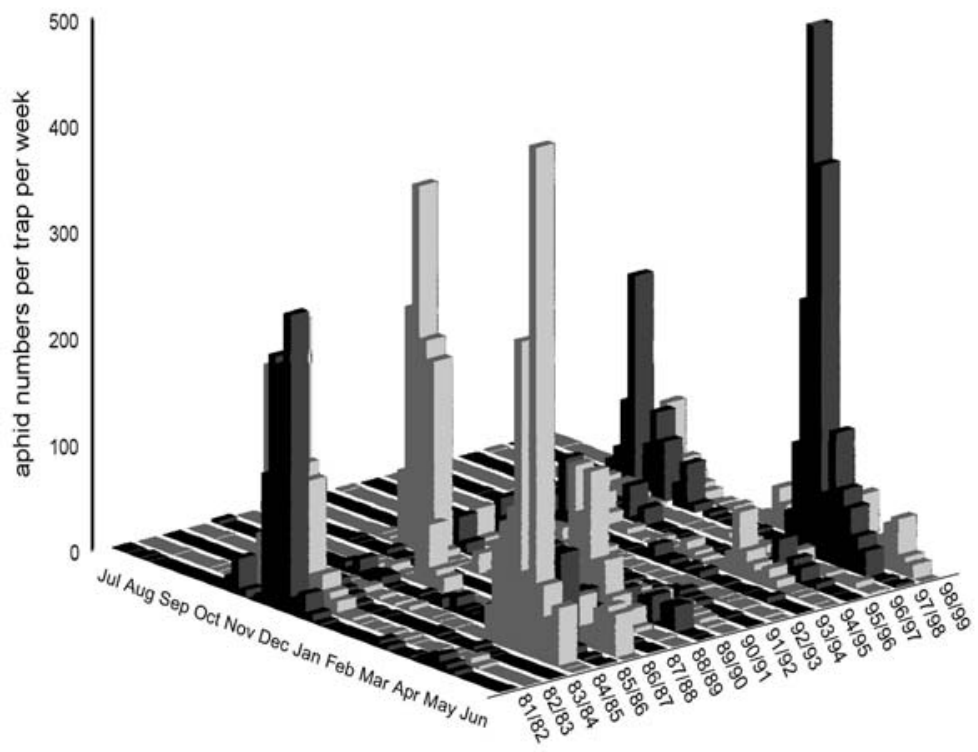

FIGURE 1: Flight patterns of the three main potato leaf roll virus vectors potato aphids collected from a $7.5 \mathrm{~m}$ high suction trap at Lincoln during 1981-99. 


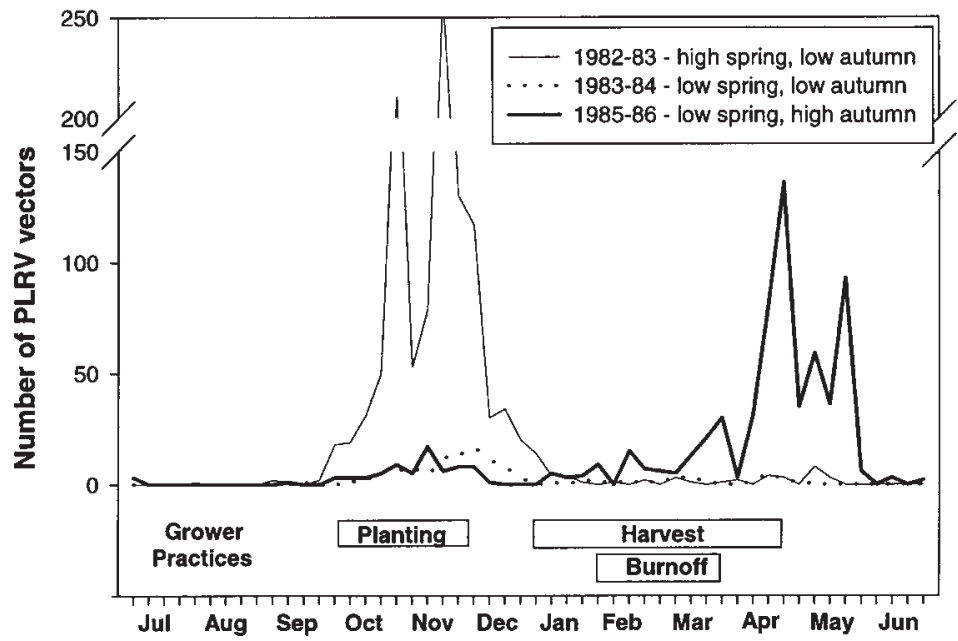

FIGURE 2: Examples of PLRV aphid vector flight patterns.

numbers than the potato aphid and the foxglove aphid. Weekly trap catches of the green peach aphid exceeded 100 aphids/week on many occasions, whereas captures of potato aphid never exceeded 20/week and foxglove aphid never exceeded 35/week. In general, more potato and foxglove aphids were trapped in spring than autumn whereas green peach aphid peaks occurred in spring and autumn although there was usually only one major peak in either season during the year.

For ease of comparison, and because any forecasting system is unlikely to distinguish between different PLRV aphid vectors, we have presented aphid flight activity for the three species combined (Fig. 1). As noted above, the green peach aphid contributes disproportionately to the numbers of aphids represented on this graph. Unless otherwise stated, the use of the term 'aphid' will refer only to the three PLRV aphid vectors.

The timing of the start of the main spring aphid flight varied from year to year, ranging from 5 October $(1982,1997)$ to 21 December (1986). Similarly, the start of the autumn flights varied from 8 February (1999) to19 April (1996). The magnitude or peak number of aphids caught per week also varied considerably throughout the sampling period. In spring, numbers of aphids ranged from as little as 7/week $(1984,1987)$ to over $250 /$ week $(1981,1982,1988)$. Similarly in autumn, aphid numbers ranged from less than 5/week $(1984,1993)$ to over 480/week $(1985,1998)$. The duration of aphid peaks also varied considerably. In spring, the time when aphid flights exceeded 10 aphids/week ranged from 1 (1985) to 14 consecutive weeks (1982). Similarly in autumn, the time when 10 aphids/week were exceeded ranged from 1 (1982, 1992) to 19 consecutive weeks (1999). In some seasons there were never more than 10 aphids/week. The magnitude and duration of flight peaks were highly correlated. Large peaks were associated with long periods of aphid flight activity.

Fig. 2 shows representative flight patterns for the three PLRV aphid vectors for three seasons and contrasts the timing of flights with the timing of potato growing practices in Canterbury. It illustrates several points.

- Aphid flights in late spring coincide with the main period of potato planting and emergence.

- Aphid flights in autumn overlap with the end of the main potato harvest.

- In some years, crops may be threatened by a relatively high risk in spring of aphid infestation and virus transmission as a result of large aphid flights but a relatively low risk in autumn (e.g. 1982-83). 
- In some years crops may experience a relatively low risk in spring of aphid infestation and virus transmission, but a relatively high risk in autumn as a result of aphid flights (e.g. 1985-1986). It is important to note that in 1986 aphid flights were high during the period of burn-off so that seed crops may also have been at risk from aphids and virus. A similar situation occurred in the autumn of 1998 when record numbers of aphids were caught.

- In some years crops may experience a relatively low risk in spring and autumn as a result of low flight activity throughout the year (e.g. 1983-84).

- In some years crops may experience a relatively high risk in spring and autumn as a result of large flight peaks at both these times (e.g. 1988-89).

Management of aphid-transmitted viruses in potatoes is based on an understanding of aphids and their flight activity and includes the following practices: growing potatoes in areas where aphid flights are low to minimize aphid invasion (e.g. seed crops on the upper Canterbury plains); use of virus-tested certified seed potatoes; use of virus-resistant cultivars; seed treatment with systemic insecticides to kill aphids flying into the crop; crop monitoring by growers for aphids to indicate the need for pest controls; insecticide applications to foliage to kill aphids flying into the crop and to minimize spread of wingless forms within the crop; burning-off foliage (especially seed crops) to prevent virus infection in autumn as aphid flights increase; removal of virus-infected plants to limit spread within the crop; removal of weeds to limit localized aphid flights and virus spread within the crop; and late planting to avoid late spring aphid flights (Close 1965; Claridge 1972; Fletcher 1997).

Given the time and money devoted to keeping viruses out of potato crops (especially seed potatoes), growers would benefit considerably from up-to-date information on aphid flight activity. This would enable growers to estimate the risk of aphid infestation and virus transmission in their crops and allow them to make informed pest management decisions. Growers would benefit from increased potato yields in seasons of high aphid flights by applying more control measures, and a reduction in control costs in seasons of low aphid flights. Minimising insecticide applications would also reduce the development of aphid resistance to insecticides (Cameron 1996).

The work reported here represents a first step in the development of a potato aphid monitoring virus forecasting system. Such a system will require a network of suction traps and information transfer technologies which have already been established in Canterbury for the cereal aphid monitoring virus forecasting system (Teulon et al. 1999). Work is presently underway to define the pest status of aphid species infesting potatoes, and to determine the relationship between the number of aphids caught in suction traps with aphid infestation and virus infection in potato crops.

\section{REFERENCES}

Cameron, P.J., 1996. Green peach aphid resistance management strategy. Pp 207-209 In: Pesticide resistance: prevention and management, G.W. Bourdot and D.M. Suckling (Eds); New Zealand Plant Protection Society, Rotorua.

Claridge, J.H., 1972. Potatoes (Genus Solanum). Pp 229-296 In: Arable Farm Crops of New Zealand, A.H. \& A.W. Reed, Wellington.

Close, R.C., 1965. Control of leaf roll virus in potatoes. Proc. 18th N.Z. Weed and Pest Control Conf: : 197-246.

Cottier, W., 1931. An insect survey of potato foliage in New Zealand.N.Z. J. Sci Tech. 3: 125-139.

Farrell, J.A. and Stufkens, M.W., 1992. Cereal aphid flights and barley yellow dwarf virus infection of cereals in Canterbury, New Zealand. N.Z. J. Crop Hort. Sci. 20 : 407-412.

Fletcher, J., 1997. Management of potato viruses. Commercial Grower 52 (10): 3335.

Johnson, C.G. and Taylor, L.R., 1955. The development of large suction traps for airborne insects. Ann. Appl. Biol. 43: 51-62. 
Lowe, A.D., 1967. Sowing date as an aphid-virus control technique. Proc. 20th N.Z. Weed and Pest Control Conf:: 214-216.

Lowe, A.D., 1968. Alate aphids trapped over 8 years at two sites in Canterbury, New Zealand. N.Z. J. Agric. Res. 11: 829-47.

Lowe, A.D., 1973. Perspectives in aphid biology. The Entomological Society of New Zealand, Christchurch. $121 \mathrm{pp}$.

Martin, N.A. and Workman, P.J., 1997. Melon aphid (Aphis gossypii) resistance to pesticides. Proc. 50th N.Z. Plant Prot. Conf.: 405-408.

Miln, A.J., 1978. Potato aphids in the Manawatu. Proc. 31st N.Z. Weed and Pest Control Conf. 79-84.

Ovenden, G.E., Anderson, J.A.D., Armstrong, S.D. and Mitchell, W.J.P., 1985. Pathogen tested potatoes in New Zealand. II. Field evaluation. Pp 39-42 In: Potato growing: a changing scene, G.D. Hill and G.S. Wratt (Eds); Agronomy Society of New Zealand Special Publication No. 3.

Radcliffe, E.B., Ragsdale, D.W. and Flanders, K.L., 1993. Management of aphids and leafhoppers, Pp 117-136 In: Potato health management, R.C. Rowe (Ed); APS Press, New York.

Rongai, D., Cerato, C., Martelli, R. and Ghendini, R., 1998. Aspects of insecticide resistance and reproductive biology of Aphis gossypii Glover on seed potatoes. Potato Res. 41: 29-37.

Salazar, L.F., 1996. Potato viruses and their control. International Potato Centre, Peru.

Teulon, D.A.J. and Stufkens, M.A.W., 1998. Forecasting barley yellow dwarf virus in Canterbury winter-sown cereals. Proc. 51st N.Z. Plant Prot. Conf.: 263.

Teulon D.A.J., Stufkens, M.A.W., Nicol, D. and Harcourt, S.J., 1999. Forecasting barley yellow dwarf virus in autumn-sown cereals in 1998. Proc. 52nd N.Z. Plant Prot. Conf: : 187-191.

Webby, G.N., 1988. Studies on the luteoviruses: potato leaf roll virus, beet western yellows virus and tomato yellow top virus. PhD Thesis, Lincoln University, Canterbury, New Zealand. 